\title{
A prospective study of mortality among middle-aged diabetic patients (the London cohort of the WHO Multinational Study of Vascular Disease in Diabetics) I: causes and death rates
}

\author{
N. J. Morrish ${ }^{1}$, L. K. Stevens ${ }^{3}$, J.Head ${ }^{3}$, J.H.Fuller ${ }^{3}$, R. J. Jarrett ${ }^{2}$ and H. Keen ${ }^{1}$ \\ ${ }^{1}$ Unit for Metabolic Medicine and ${ }^{2}$ Department of Community Medicine, United Medical and Dental Schools (Guy's Campus), and \\ ${ }^{3}$ Department of Community Medicine, University College and Middlesex School of Medicine, London, UK
}

\begin{abstract}
Summary. The 497 members of the London Cohort of the WHO Multinational Study of Vascular Disease in Diabetics have been followed for mortality from 1975 to 1987. During this period 92 patients died. The most common cause of death was myocardial infarction: $36(39.1 \%)$ deaths, heart disease was responsible for $51.1 \%$ of deaths and all cardiovascular disease for $55.4 \%$. Neoplastic disease accounted for $25 \%$ of the deaths and diabetic nephropathy for $5.4 \%$. Agestandardised mortality rates were higher in men than in women in both Type 1 (insulin-dependent) diabetes and Type 2 (non-insulin-dependent) diabetes. Standardised mor-
\end{abstract}

tality ratios for the first and second five year follow-up periods were higher for men than for women in Type 2 diabetes but were higher for women than men in Type 1 . The results suggest that the female survival advantage seen in the general population may persist in Type 2 but not in Type 1 diabetes.

Key words: Mortality, Type 1 (insulin-dependent) diabetes, Type 2 (non-insulin-dependent) diabetes, standardised mortality ratio, myocardial infarction, ischaemic heart disease.
The excess mortality in men and women with diabetes from developed countries can be attributed in the main to an increased prevalence of vascular disease [1] and also to the occurrence of specific complications particularly diabetic nephropathy [2]. We report on the absolute and comparative rates and causes of deaths occurring over a 10-12 year follow-up of the 497 members of the London Cohort of the WHO Multinational Study of Vascular Disease in Diabetics (WHO Study).

The age range of the men and women recruited for the WHO study was 35-54 years; this was chosen to display the emergence of the vascular complications of diabetes without being unduly distorted by mortality from them. Recruitment was separate for either sex and was stratified in three groups across the age range. Any cohort of patients with diabetes is to an unknown extent a survivor population but the effect of diabetes-related mortality before 35 years of age is relatively small and is likely to be restricted to those with Type 1 (insulin-dependent) diabetes [3]. The duration of the diabetic state is known to be an important factor in the development of some of the complications of diabetes. Patient recruitment was therefore also stratified to represent a spectrum of duration of diabetes for each segment of the age range.

\section{Subjects and methods}

The London cohort of 35-54 year old men and women with diabetes, stratified as indicated by gender, age and duration was drawn by a randomised procedure from the diabetic out-patient clinics of King's College Hospital, Guy's Hospital and St Thomas's Hospital and was examined initially between 1975-1977 [4]. The inception cohort consisted of 254 men and 243 women. A diabetic subject was defined as a patient who had been diagnosed at least one year earlier and who was receiving treatment for diabetes at one of the participating centres at entry to the study. In this report Type 1 (insulin-dependent) diabetes is defined as those patients who started insulin treatment within one year of diagnosis and who continued on this treatment without break; using this definition 243 of the London patients were insulin-dependent and 254 had Type 2 (non-insulin-dependent) diabetes. The cohort broken down by age-range, sex and diabetes type is shown in Table 1 .

\section{Mortality follow-up}

All study participants were registered with the National Health Service Central Register which provided copies of death certificates as deaths have occurred. The survivors have recently been systematically re-studied thus positively identifying those still alive and leaving a small group (5\%) whose fate is unknown. Where possible the information from the death certificates has been supplemented by 
Table 1. The London WHO Study Cohort at baseline by sex, agegroup and diabetes type

\begin{tabular}{lccccc}
\hline $\begin{array}{l}\text { Baseline age } \\
\text { (years) }\end{array}$ & \multicolumn{2}{l}{$\begin{array}{l}\text { Type 1 (insulin-de- } \\
\text { pendent) diabetes }\end{array}$} & & \multicolumn{2}{c}{$\begin{array}{l}\text { Type 2 (non-insulin- } \\
\text { dependent) diabetes }\end{array}$} \\
\cline { 2 - 3 } \cline { 5 - 6 } & Male & Female & & Male & Female \\
\hline $35-41$ & 47 & 36 & & 24 & 17 \\
$42-48$ & 33 & 44 & & 43 & 43 \\
$49-55$ & 38 & 45 & & 69 & 58 \\
& 118 & 125 & & 136 & 118 \\
\hline
\end{tabular}

Table 2. The State of the Cohort at 31 July 1987

\begin{tabular}{|c|c|c|c|c|c|}
\hline & \multirow[t]{2}{*}{ All } & \multicolumn{2}{|c|}{$\begin{array}{l}\text { Type } 1 \text { (insulin-de- } \\
\text { pendent) diabetes }\end{array}$} & \multicolumn{2}{|c|}{$\begin{array}{l}\text { Type } 2 \text { (non-insulin- } \\
\text { dependent) diabetes }\end{array}$} \\
\hline & & Male & Female & Male & Female \\
\hline Living & 387 & 97 & 97 & 99 & 94 \\
\hline Dead & 92 & 19 & 23 & 32 & 18 \\
\hline \multirow[t]{2}{*}{ Unknown } & 18 & 2 & 5 & 5 & 6 \\
\hline & 497 & 118 & 125 & 136 & 118 \\
\hline
\end{tabular}

autopsy reports and/or clinical records. Information (death certificates, autopsy reports and clinical records) relating to cause of death for each patient was reviewed by a Mortality Committee consisting of two of the authors (NJM, JHF) and two independent physicians who reviewed similar data for all of the WHO Centres. A single underlying cause of death was assigned in each case which was then coded according to the International Classification of Diseases (9th revision, 1977) [5].

\section{Statistical analysis}

Official population statistics for the Greater London area [6] were used to calculate the death rates; age-adjusted mortality rates were calculated by the direct method and standardised mortality ratios (SMR) were calculated by the indirect method. $95 \%$ confidence intervals were calculated for the age adjusted rates according to Morris and Gardner [7].

\section{Results}

\section{Mortality experience}

The life-death status of the cohort up to 31 July 1987 is shown in Table 2 where the deaths are categorised by sex and diabetes type.

The most common underlying cause of death was myocardial infarction (ICD code 410) which accounted for $36(39.1 \%$ ) of all deaths (Table 3 ). Cardiac causes of death (ICD $410-429$ ) accounted for $51.1 \%$ of deaths ( $43 \%$ in patients with Type 1 diabetes and $58 \%$ in patients with Type 2 diabetes). Cardiovascular disease (ICD codes 390 459 and 798.1$)$ caused $57.6 \%$ of the deaths $(50 \%$ for patients with Type 1 diabetes and $64 \%$ for patients with Type 2 diabetes). Neoplastic diseases (ICD Codes 140 239) were the second most common cause of death with 23 (25\%) cases. Diabetic nephropathy (ICD code 250.3) accounted for five deaths $(5.4 \%)$; two in Type 1 diabetes and three in Type 2 diabetes. Diabetes itself (ICD code 250,
Table 3. Underlying causes of death

\begin{tabular}{|c|c|c|c|c|c|}
\hline \multirow[t]{2}{*}{$n(\%)$} & \multirow[t]{2}{*}{ Total } & \multicolumn{2}{|c|}{$\begin{array}{l}\text { Type } 1 \text { (insu- } \\
\text { lin-dependent) } \\
\text { diabetes }\end{array}$} & \multicolumn{2}{|c|}{$\begin{array}{l}\text { Type } 2 \text { (non-in- } \\
\text { sulin-depend- } \\
\text { ent) diabetes }\end{array}$} \\
\hline & & Male & Female & $\overline{\text { Male }}$ & Female \\
\hline $\begin{array}{l}\text { Myocardial infarction } \\
\text { ICD } 410\end{array}$ & $\begin{array}{l}36 \\
(39.1)\end{array}$ & $\begin{array}{l}8 \\
(42.1)\end{array}$ & $\begin{array}{l}5 \\
(21.7)\end{array}$ & $\begin{array}{l}15 \\
(46.9)\end{array}$ & $\begin{array}{l}8 \\
(44.4)\end{array}$ \\
\hline $\begin{array}{l}\text { Other IHD } \\
\text { ICD } 411-4\end{array}$ & $\begin{array}{l}9 \\
(9.8)\end{array}$ & $\begin{array}{l}1 \\
(5.3)\end{array}$ & $\begin{array}{l}4 \\
(17.4)\end{array}$ & $\begin{array}{l}2 \\
(6.3)\end{array}$ & $\begin{array}{l}2 \\
(11.1)\end{array}$ \\
\hline $\begin{array}{l}\text { Other cardiac disease } \\
\text { ICD } 415-429\end{array}$ & $\begin{array}{l}2 \\
(2.2)\end{array}$ & - & - & $\begin{array}{l}1 \\
(3.1)\end{array}$ & $\begin{array}{l}1 \\
(5.6)\end{array}$ \\
\hline $\begin{array}{l}\text { Cerebrovascular } \\
\text { ICD } 430-438\end{array}$ & $\begin{array}{l}4 \\
(4.3)\end{array}$ & - & $\begin{array}{l}2 \\
(8.7)\end{array}$ & $\begin{array}{l}2 \\
(6.3)\end{array}$ & - \\
\hline $\begin{array}{l}\text { Sudden death } \\
\text { ICD } 798.1\end{array}$ & $\begin{array}{l}2 \\
(2.2)\end{array}$ & $\begin{array}{l}1 \\
(5.3)\end{array}$ & - & $\begin{array}{l}1 \\
(3.1)\end{array}$ & - \\
\hline $\begin{array}{l}\text { Neoplasms } \\
\text { ICD } 140-239\end{array}$ & $\begin{array}{l}23 \\
(25.0)\end{array}$ & $\begin{array}{l}6 \\
(31.6)\end{array}$ & $\begin{array}{l}7 \\
(30.4)\end{array}$ & $\begin{array}{l}5 \\
(15.6)\end{array}$ & $\begin{array}{l}5 \\
(27.8)\end{array}$ \\
\hline $\begin{array}{l}\text { Diabetes ICD } 250 \\
(\text { ex 250.3) }\end{array}$ & $\begin{array}{l}4 \\
(4.3)\end{array}$ & $\begin{array}{l}2 \\
(10.5)\end{array}$ & $\begin{array}{l}2 \\
(8.7)\end{array}$ & - & - \\
\hline $\begin{array}{l}\text { Diabetic nephropathy } \\
\text { ICD } 250.3\end{array}$ & $\begin{array}{l}5 \\
(5.4)\end{array}$ & $\begin{array}{l}1 \\
(5.3)\end{array}$ & $\begin{array}{l}1 \\
(5.3)\end{array}$ & $\begin{array}{l}2 \\
(4.3)\end{array}$ & $\begin{array}{l}1 \\
(6.3)\end{array}$ \\
\hline $\begin{array}{l}\text { Other renal disease } \\
\text { ICD } 580-9\end{array}$ & $\begin{array}{l}1 \\
(1.1)\end{array}$ & - & $\begin{array}{l}1 \\
(4.3)\end{array}$ & - & - \\
\hline Unknown & $\begin{array}{l}1 \\
(1.1)\end{array}$ & - & - & $\begin{array}{l}1 \\
(3.1)\end{array}$ & - \\
\hline Suicide & $\begin{array}{l}2 \\
(2.2)\end{array}$ & - & $\begin{array}{l}1 \\
(4.3)\end{array}$ & $\begin{array}{l}1 \\
(3.1)\end{array}$ & - \\
\hline Other & $\begin{array}{l}3 \\
(3.3)\end{array}$ & - & - & $\begin{array}{l}2 \\
(6.3)\end{array}$ & $\begin{array}{l}1 \\
(5.6)\end{array}$ \\
\hline Total & 92 & 19 & 23 & 32 & 18 \\
\hline
\end{tabular}

IHD: ischaemic heart disease; ICD International Classification of diseases

except 250.3) was the underlying cause in four deaths; two were due to diabetic ketoacidosis and two from diabetic coma (unspecified). Table 4 shows the crude proportions of deaths due to cardiovascular and non-cardiovascular causes by gender in the two types of diabetes. Cardiovascular causes are responsible for a higher proportion of the deaths in patients with Type 2 diabetes than in patients with Type 1 diabetes.

\section{Mortality rates}

Age-adjusted death rates per 1000 person years during the period 1975-1987 are shown in Table 5. The rates for all cause mortality for men were higher than those for women in each diabetes type but the difference was much more marked among patients with Type 2 diabetes than in those with Type 1 diabetes. The rates for cardiovascular mortality were lower for women in each diabetes type and among women were lower in those with Type 2 diabetes than those with Type 1 diabetes.

SMRs for the first two five year sequential follow-up periods have been calculated for each sex and diabetes type using the figures for the Greater London area as the standard population (Fig. 1). The patterns are different within each diabetes type with female subjects having con- 
Table 4. Deaths from cardiovascular and non-cardiovascular causes $(n(\%))$

\begin{tabular}{lllllll}
\hline & Total & \multicolumn{2}{c}{$\begin{array}{l}\text { Type 1 (insulin-de- } \\
\text { pendent) diabetes }\end{array}$} & \multicolumn{2}{c}{$\begin{array}{l}\text { Type 2 (non-insulin- } \\
\text { dependent) diabetes }\end{array}$} \\
\cline { 3 - 4 } & & Male & Female & & Male & Female \\
\hline All cardiovas- & 51 & 9 & 11 & & 20 & 11 \\
cular & $(55.4)$ & $(47.4)$ & $(47.8)$ & & $(62.5)$ & $(61.1)(\%)$ \\
All non-cardio- & 41 & 10 & 12 & & 12 & 7 \\
vascular & $(44.6)$ & $(52.6)$ & $(52.2)$ & & $(37.5)$ & $(38.9)$ \\
Total & 92 & 19 & 23 & & 32 & 18 \\
\hline
\end{tabular}

Table 5. Age adjusted mortality rates per 1000 person years in the cohort over the follow-up period $(95 \% \mathrm{CI})$

\begin{tabular}{llllll}
\hline & \multicolumn{2}{l}{$\begin{array}{l}\text { Type 1 (insulin-depend- } \\
\text { ent) diabetes }\end{array}$} & & \multicolumn{2}{l}{$\begin{array}{l}\text { Type 2 (non-insulin- } \\
\text { dependent) diabetes }\end{array}$} \\
\cline { 2 - 3 } \cline { 5 - 6 } & Male & Female & & Male & Female \\
\hline All-cause & 19.4 & 15.34 & & 22.59 & 9.1 \\
mortality & $(9.6-29.2)$ & $(9.8-20.9)$ & & $(13.7-31.5)$ & $(4.5-13.7)$ \\
Circulatory & 11.02 & 8.40 & & 13.89 & 5.45 \\
mortality & $(3.7-18.3)$ & $(7.1-20.7)$ & & $(3.9-12.9)$ & $(1.9-9.0)$ \\
\hline
\end{tabular}

siderably higher SMRs in each 5 year period among patients with Type 1 diabetes and male subjects having higher SMRs in the patients with Type 2 diabetes.

\section{Discussion}

Cardiovascular disease is the principal cause of the excess and premature mortality seen among diabetic patients when compared to the general population. Arteriosclerotic disease was responsible for $75.6 \%$ of all deaths in the Joslin Clinic population between 1969 and 1979 [8]. A British study of deaths occurring in diabetic patients under 50 years of age found that vascular causes accounted for $41 \%$ of the deaths [9]. An analysis of death certificates mentioning diabetes in England and Wales for 1975 and 1976 found that the underlying cause category

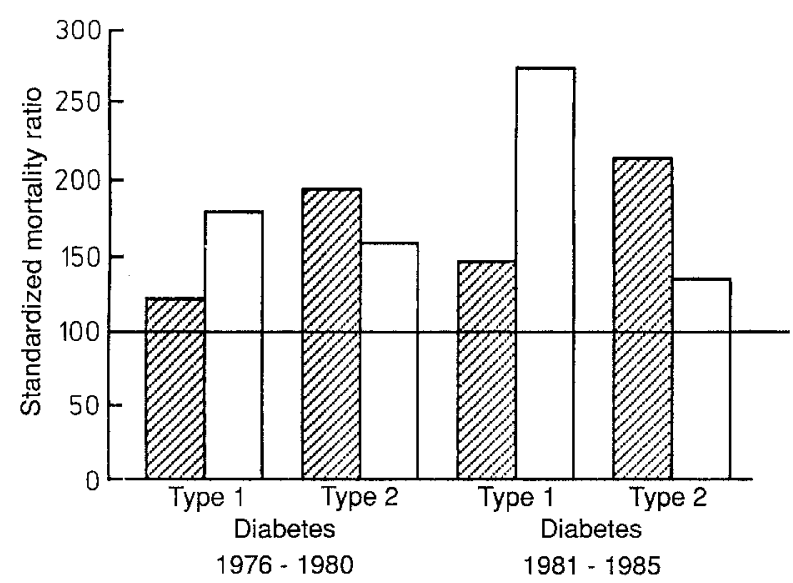

Fig. 1. Standardised mortality ratios in the male ( $\square$ ) and female ( $\square$ ), subjects by type of diabetes during each of the first two fiveyear follow-up periods 'all circulatory diseases' was assigned to $51 \%$ of deaths in males and $52 \%$ of deaths in females [10]. These results are very similar to ours and confirm the importance of cardiovascular disease as a cause of death in this age-group of the diabetic population. The patients of the London WHO cohort were drawn from hospital clinic attenders and are therefore not as representative as a population sample would have been but are of value as most of the patients with diabetes in the age range studied would be attending a hospital clinic.

Some authors have indicated that the female survival advantage seen in the general population is lost for diabetic women $[3,11]$. In this group of British diabetic patients the age adjusted mortality rates are similar in men with either type of diabetes and are higher than those for the women. Age adjusted mortality rates from both all cause and cardiovascular mortality are higher among women with Type 1 diabetes than those with Type 2 diabetes. The SMRs show that women with Type 1 diabetes fare considerably worse than those with Type 2 diabetes, they also suggest that men with Type 2 diabetes in this age group have a greater excess mortality than men with Type 1 diabetes. Although our numbers are small these results would indicate that some of the female survival advantage may be retained in Type 2 diabetes. The results in Table 5 suggest that the low all cause mortality rate for women with Type 2 diabetes in this group is due to lower rates of death from both cardiovascular and non-cardiovascular causes. A recent population sample from the USA [12] (in which $80 \%$ of the patients were non-insulin treated) found no evidence of loss of female survival advantage whereas a long-term follow-up study of patients with Type 1 diabetes [13] found no difference in mortality between men and women. Kleinman et al. [12] have reviewed several North American studies and conclude that although four out of five previous studies did report a reduction of the 'female advantage' these were based on very small numbers. It therefore seems possible that the presence, or not, of a degree of female survival advantage in diabetes may be a function of the type of diabetes and not of the diabetic state itself. Our study would support other evidence that the female survival advantage seen in the general population may continue in Type 2 but not in Type 1 diabetes.

Acknowledgements. The project was supported by a Medical Research Council Project Grant. We would like to thank the staff of the Diabetic Departments of King's College and St Thomas's Hospitals for their co-operation. We are grateful to Dr E Jepson and Dr K Ball for their participation in the Mortality Committee.

\section{References}

1. Pyorala K, Laakso M, Uusitopa M (1987) Diabetes and atherosclerosis: an epidemiologic view. Diab Rev 3: 463-524

2. Moloney A, Tunbridge WMG, Ireland JT, Watkins PJ (1983) Mortality from diabetic nephropathy in the United Kingdom. Diabetologia 25: 26-30

3. Krolewski AS, Warram JH, Christlieb AR (1985) Onset, course and prognosis of diabetes mellitus. In: Marble A, Krall LP, 
Christlieb AR, Soeldner JS (eds) Joslins diabetes mellitus, 12th edn. Lea \& Febiger, Philadelphia, pp 251-777

4. The World Health Organisation Multinational Study of Vascular Disease in diabetics (1985) Prevalence of small vessel and large vessel disease in diabetic patients from 14 centres. Diabetologia 28 [Suppl]: 615-640

5. Manual of the International Statistical Classification of Diseases, Injuries and Causes of Death (9th Revision) (1977) World Health Organisation, Geneva

6. Office of Population Censuses and Surveys (1980) Mortality Statistics, Area, 1980. Series DH5 No 7. OPCS

7. Morris JA, Gardner MJ (1989) Calculating confidence intervals for relative risks, odds ratios, and standardised ratios and odds. In: Gardner MJ, Altman DG (eds) Statistics with Confidence. British Medical Journal, London, pp 50-63

8. Entmacher PS, Krall LP, Kranczer SN (1985) Diabetes mortality from vital statistics. In: Marble A, Krall LP, Christlieb AR, Soeldner JS (eds) Joslins diabetes mellitus, 12th edn. Lea \& Febiger, Philadelphia, pp 278-297

9. Tunbridge WMG (1981) Factors contributing to deaths of diabetics under 50 years of age. Lancet II: $569-572$

10. Fuller JH, Elford J, Goldblatt P, Adelstein AM (1983) Diabetes mortality: new light on an underestimated public health problem. Diabetologia 24: 336-341
11. Panzram G, Zabel-Langhennig R (1981) Prognosis of diabetes mellitus in a geographically defined population. Diabetologia 20: $587-591$

12. Kleinman JC, Donahue RP, Harris MI, Finucane FF, Madans JH, Brock DB (1988) Mortality among diabetics in a national sample. Am J Epidemiol 128: 389401

13. Krolewski AS, Kosinski EJ, Warram JH, Leland S, Busick EJ, Asmal AC, Rand LI, Christlieb AR, Bradley RF, Kahn CR (1987) Magnitude and determinants of coronary artery disease in juvenile onset, insulin-dependent diabetes mellitus. Am J Cardiol 59: $750-755$

Received: 12 December 1989

and in revised form: 20 February 1990

Dr. N.J.Morrish

Unit for Metabolic Medicine

4th Floor, Hunt's House

Guy's Hospital

London SEI 9RT

UK 